\title{
Surgical ventricular restoration in patients LV aneurisms and congestive heart failure
}

\author{
B Baev*, D Petkov, R lliev, D Kiuchukov, G Nachev \\ From 23rd World Congress of the World Society of Cardio-Thoracic Surgeons \\ Split, Croatia. 12-15 September 2013
}

\section{Background}

SVR is increasingly performed in patients with LV aneurisms and CHF. We report our ten year results with different surgical reconstructions and two different methods of myocardial protection.

\section{Methods}

Between January 2003 and January 2013, 390 consecutive patients underwent SVR, of whom 219 with ICHF, NYHA- class III- IV and EF $<35 \%$ were selected for this study. The patients are divided in two groups: Group I -113 pts with vented fibrillating heart, Group II -106 pts with cardioplegic arrest (ante/retrograde cold blood cardioplegia). The patients in both groups have similar preand intra-operative parameters. Euroscore averaged 11,2 $(6,8-57,9)$. Two surgical techniques were used: Dor procedure in 119 patients and linear resection in 100 patients. Concomitant to SVR, mitral valve reconstructions, LV septoplasty, CABG and trombectomy have been performed in 44 (20\%), 28 (12,3\%), 215 (98,1\%) and 71 $(32,4 \%)$ patients, respectively.

\section{Results}

Mean follow-up was $57 \pm 21$ months. The operative mortality was $8,2 \%$ (18 pts). In both groups EF improved from $29 \%$ to $36,6 \%$, NYHA-class was reduced from 3,3 to 1,5 , LVEDV was reduced by $62 \pm 43 \mathrm{ml}$ and LVESV- by $55 \pm$ $47 \mathrm{ml}$ post-operatively. Significant differences between Group I and Group II were found in the use of inotropes $60 \%$ versus $84 \%$, use of IABP $25,4 \%$ versus $43,4 \%$, duration of mechanical ventilation 23,6 versus 47,9 hours and length of hospital stay 8,8 versus 12,8 days. No difference was found between the Dor procedure and linear resection

\footnotetext{
* Correspondence: boian_baev@hotmail.com

Department of Cardiac Surgery, 'St. Ekaterina' University Hospital, Sofia, Bulgaria
}

in terms of mortality, NYHA class and LV volume reduction.

\section{Conclusions}

SVR shows good results for the treatment of patients with ICHF and $\mathrm{EF}<35 \%$. The method of vented fibrillating heart showed lower occurrence of LCO and significantly shorter duration of mechanical ventilation and length of hospital stay in comparison to the method of cardioplegic arrest.

Published: 11 September 2013

doi:10.1186/1749-8090-8-S1-0168

Cite this article as: Baev et al:: Surgical ventricular restoration in patients LV aneurisms and congestive heart failure. Journal of Cardiothoracic Surgery 2013 8(Suppl 1):0168. and take full advantage of:

- Convenient online submission

- Thorough peer review

- No space constraints or color figure charges

- Immediate publication on acceptance

- Inclusion in PubMed, CAS, Scopus and Google Scholar

- Research which is freely available for redistribution

Submit your next manuscript to BioMed Central www.biomedcentral.com/submit 